\title{
Studies on the Bile Salt Stimulated Lipolytic Activity of Human Milk Using Whole Milk as Source of Both Substrate and Enzyme. I. Nutritional Implications
}

\author{
BARBARA HALL AND D. P. R. MULLER ${ }^{(37)}$ \\ Department of Child Health, Institute of Child Health, 30 Guilford Street, London, WCIN IEH, England
}

\begin{abstract}
Summary
The lipolytic activity of human milk was assayed using whole fresh milk as source of both enzyme and substrate. Bile salts and specifically glycine rather than taurine conjugates were essential for activity; a concentration of $2 \mathrm{mM}$ being optimal. The lipid concentration and lipolytic activity increased significantly $(P<$ 0.01 and $<0.02$ respectively) during the course of a feed. The lipid concentration and lipolytic activity were compared in immature and mature milks (less and greater than 15 days postpartum respectively). The lipolytic activity remained constant whereas the lipid concentration was significantly greater in the mature than the immature milks $(P<0.001)$. In none of the milks was the substrate concentration limiting. The $\%$ hydrolysis of ingested triglyceride in the immature and mature milks was calculated to be approximately 40 and $20 \%$ respectively in $2 \mathrm{~h}$, which is the estimated transit time from the duodenum to ileum. The major lipolytic products were free fatty acids and in general the enzyme showed little specificity for different fatty acids of triglyceride.
\end{abstract}

\section{Speculation}

The characteristics of the bile salt stimulated lipase activity of human milk suggest that it is involved in the digestion of milk fat in the small intestine of the infant and that it complements rather than duplicates pancreatic lipase activity. The activity maintained throughout lactation suggests that this lipase plays an important nutritional role in the newborn.

Marfan (26) first described the presence of a lipase in human milk in 1901. Freudenberg (9) subsequently showed that the lipolytic activity was stimulated by bile salts and, more recently, several groups have confirmed the presence of an active lipolytic system in human milk $(3,14,20,22,24)$.

At least two different lipases (glycerol ester hydrolases) have been described in human milk. First, a lipase is present in the milk of many species which requires added serum for activity and has similar properties to lipoprotein lipase (21). It appears that the function of this enzyme is to facilitate the uptake by the mammary gland of fatty acids from circulating triglycerides for incorporation into milk lipids. Its presence in milk probably represents "leakage" from the mammary gland and it is unlikely to play a physiologic role in the lipolysis of milk triglycerides. The second lipolytic activity is stimulated by bile salts and has been found only in the milk of the human and gorilla $(10,20)$. It appears to represent a true mammary gland secretion and hydrolyses both long chain triglycerides and vitamin A esters (8) under the conditions found in the small intestine.

Almost half of the total calories contained in human breast milk are present as lipid and are consumed at a time when pancreatic lipase activity and bile salt pool size are reduced compared to adults $(30,33)$. Yet the newborn is still able to absorb approximately $90 \%$ of its dietary lipid (31). It has, therefore, been suggested that the newborn may be more dependent than the adult on other lipolytic systems such as lingual, gastric, mucosal and the bile salt stimulated milk lipase (15).

In this study we report some observations on the bile salt stimulated milk lipase using fresh human breast milk as a source of both enzyme and substrate. This approach approximates more closely the in vivo conditions than the more conventional assays which have used either skimmed milk or a purified preparation of the lipase as the enzyme source with an artificial triglyceride emulsion as the substrate.

\section{MATERIALS AND METHODS}

Subjects. Forty-five samples of human milk were collected from fourteen women from the fourth day to the 71 st wk postpartum. One woman provided 25 samples over this period. The milk was collected by a hand operated breast pump between 7 and 10 a.m., when, unless otherwise stated, the baby had stopped feeding at the breast. It was kept at room temperature for $2-4 \mathrm{~h}$ and assayed on the day of collection. All the infants studied were fully breastfed.

Assay of lipolytic activity. Lipolytic activity was routinely assayed in the following manner. Human milk was diluted 2.5-fold with $0.25 \mathrm{M}$ glycine $/ \mathrm{NaOH}$ buffer $(\mathrm{pH} 8.5$ ) containing mercaptoethanol $(0.02 \%)$, crystamycin (Glaxo Laboratories Limited; $16 \mu \mathrm{g}$ penicillin $/ \mathrm{ml}$ ), and $2 \mathrm{mM}$ sodium glycocholate (Sigma Chemical Company Limited) and incubated at $37^{\circ} \mathrm{C}$ with continuous shaking. The addition of mercaptoethanol and crystamycin did not interfere with enzymatic activity. Duplicate $0.5 \mathrm{ml}$ aliquots were withdrawn immediately and at fixed times and added to $10 \mu \mathrm{l}$ of $20 \%$ sulphuric acid. The free fatty acids were extracted three times with $10 \mathrm{ml}$ petroleum ether $\left(40-60^{\circ} \mathrm{C}\right)$ saturated with $87 \%$ ethanol (11) and containing 2:6 di-tert-butyl-p-cresol (10 mg/liter) as an antioxidant. The upper phases containing the free fatty acids were combined and titrated against freshly prepared $0.01 \mathrm{M}$ ethanolic $\mathrm{NaOH}$ with $1 \%$ phenolphthalein as indicator. The exact concentration of the ethanolic $\mathrm{NaOH}$ was determined on each occasion by titration against a standard solution of $0.01 \mathrm{M}$ hydrochloric acid (volumetric solution supplied by BDH Chemicals Limited). The titration and extraction procedures were validated by assaying 1-20 $\mu$ mole of heneicosanoic acid (C 21:0) obtained from Sigma Chemical Company Limited. Direct titration gave a quantitative assay of the fatty acid. Extraction of 1-5 $\mu$ mole fatty acid gave recoveries of $100 \%$. Greater than $90 \%$ recoveries were obtained for 5-20 $\mu$ mole amounts of fatty acid. The amount of free fatty acids produced with time gave an estimate of the lipolytic activity which was expressed as $\mu$ mole fatty acid produced $\cdot \mathrm{ml}^{-1} \cdot \mathrm{h}^{-1}$. A blank containing boiled milk was included with each batch of 
analyses. The reaction rate was linear with time for up to $3 \mathrm{~h}$ and incubations were routinely continued for this period.

Kinetic studies. To produce a range of suitable substrate concentrations for the kinetic studies, milk lipid was separated from 20 $\mathrm{ml}$ milk by centrifuging at $2000 \mathrm{rpm}$ at $4^{\circ} \mathrm{C}$ for $70 \mathrm{~min}$. The infranatant (milk serum) was removed and kept on ice. The lipid (supernatant) was then diluted to $5 \mathrm{ml}$ with deionised water and warmed to $37^{\circ} \mathrm{C}$ with gentle mixing to form an homogenous emulsion. Serial dilutions of this stock substrate were then prepared to give a range of lipid concentrations from approximately 3-210 g. liter ${ }^{-1}$. The assay was then performed as described above, using $0.3 \mathrm{ml}$ of the substrate solutions, $1.0 \mathrm{ml}$ of milk serum and $1.2 \mathrm{ml}$ of the glycine buffer solution. The combined substrate and milk serum was considered to be equivalent to $1 \mathrm{ml}$ whole milk and so the final substrate concentration in the assay corresponded to approximately $2-150 \%$ of the original lipid concentration. The lipid concentration of each substrate was estimated gravimetrically (13) while the mixture was still warm.

Miscellaneous Assays. The various lipid fractions of the milk were extracted (6) and separated by thin layer chromatography using the solvent system petroleum ether $\left(40-60^{\circ} \mathrm{C}\right)$, diethyl ether, glacial acetic acid, water $(85,15,2.5,1 \mathrm{v} / \mathrm{v})$. The fractions were then quantified and the fatty acid composition determined by gas liquid chromatography (13) using margaric acid as internal standard (7). The $\mathrm{pH}$, total protein and total lipid concentrations were estimated as described previously (13).

The results are expressed throughout as mean \pm 1 S.D. and the significance of difference between mean values was assessed by the paired and unpaired Student's $t$ test as appropriate.

\section{RESULTS}

\section{pH AND TOTAL PROTEIN}

Routine estimations of $\mathrm{pH}$ and total protein concentrations were made on all the milk samples. The mean $\mathrm{pH}$ for all milks was $7.23 \pm 0.26$. There was a significant difference $(P<0.001)$ between the protein content of the 12 immature (34) milks $(<15$ days) and the 29 more mature (34) milks ( $>15$ days); the mean concentrations being $18.6 \pm 3.7$ and $12.8 \pm 2.6 \mathrm{~g} \cdot$ liter $^{-1}$ respectively.

\section{EFFECT OF BILE SALTS}

The effect of adding increasing (0-20 mM) concentrations of sodium glycocholate on lipolytic activity is shown in Figure 1. In the absence of sodium glycocholate there were only traces of activity but on addition of the bile salt, activity rose markedly reaching a plateau at a concentration of $2 \mathrm{mM}$, with only a further small increase in activity at concentrations of 10 and $20 \mathrm{mM}$. The addition of sodium taurocholate (supplied by Koch Light Laboratories Ltd. and shown to be $>98 \%$ pure) over a similar concentration range did not increase lipolytic activity. Figure 2 shows the effect on a number of different milks of adding the bile salts at a concentration of $2 \mathrm{mM}$. In the absence of bile salts, the mean activity of 11 milks from nine women was $0.93 \pm 1.06 \mu$ mole.

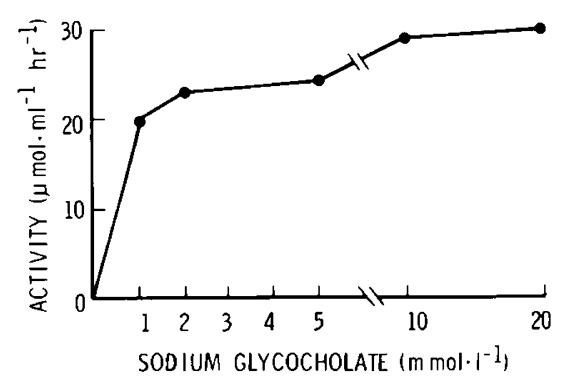

Fig. 1. Effect of increasing concentrations of sodium glycocholate on the activity of the bile salt stimulated lipase.

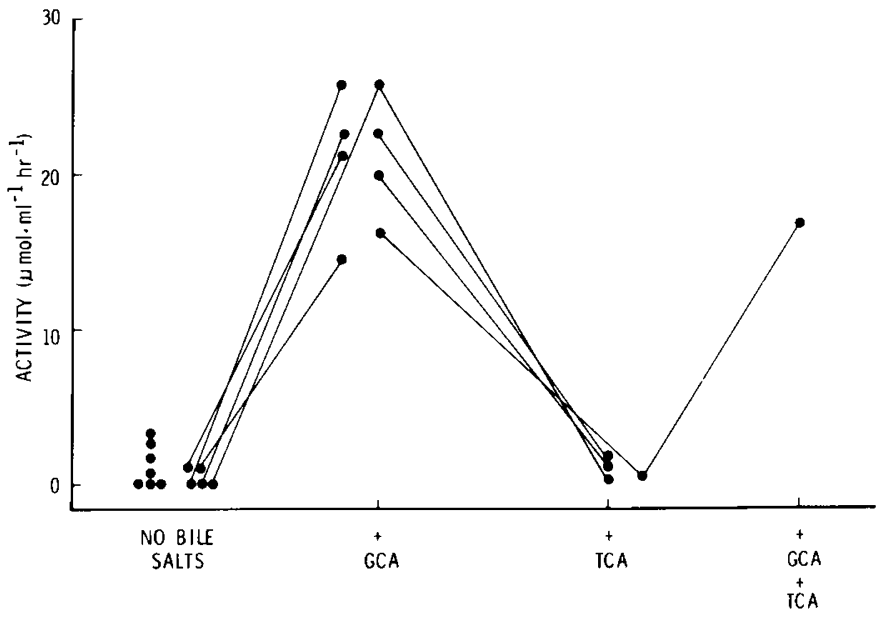

Fig. 2. The effect of sodium glyco- and taurocholate on the lipolytic activity of different milks. GCA-sodium glycocholate $(2 \mathrm{mM})$; TCAsodium taurocholate $(2 \mathrm{mM})$; and GCA + TCA-both bile salts, each at $2 \mathrm{mM}$.
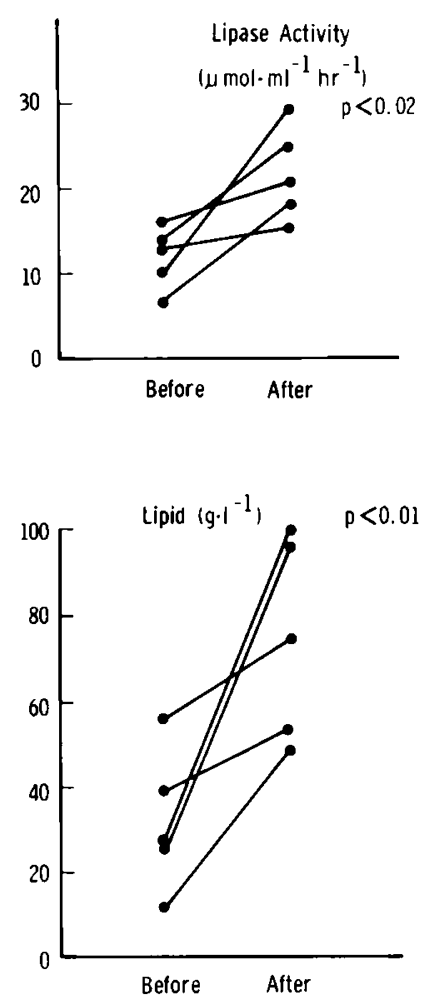

Fig. 3. The lipolytic activity and lipid concentration of mature milks collected from the same breast before and after nursing.

$\mathrm{ml}^{-1} \cdot \mathrm{h}^{-1}$. With the addition of $2 \mathrm{mM}$ sodium glycocholate, the mean activity of five of these milks increased from $0.43 \pm 0.60$ to $22.10 \pm 4.72 \mu \mathrm{mole} \cdot \mathrm{ml}^{-1} \cdot \mathrm{h}^{-1}$. Four milks, assayed with sodium glycocholate and taurocholate separately, had mean activities of $21.18 \pm 4.39$ and $0.99 \pm 0.62 \mu \mathrm{mole} \cdot \mathrm{ml}^{-1} \cdot \mathrm{h}^{-1}$ respectively. The addition of both cholate conjugates at $2 \mathrm{mM}$ to a single milk gave an activity of 16.9 compared to 15.7 and $0.44 \mu \mathrm{mole} \cdot \mathrm{ml}^{-1} \cdot \mathrm{h}^{-1}$ with glyco or taurocholate alone. This indicated that sodium taurocholate did not inhibit lipase activity.

\section{RELATIONSHIP BETWEEN MILK LIPID CONTENT AND LIPASE ACTIVITY}

Before and after feed. It is known that the milk fat content rises during the course of a feed $(12,23)$. It was, therefore, of interest 


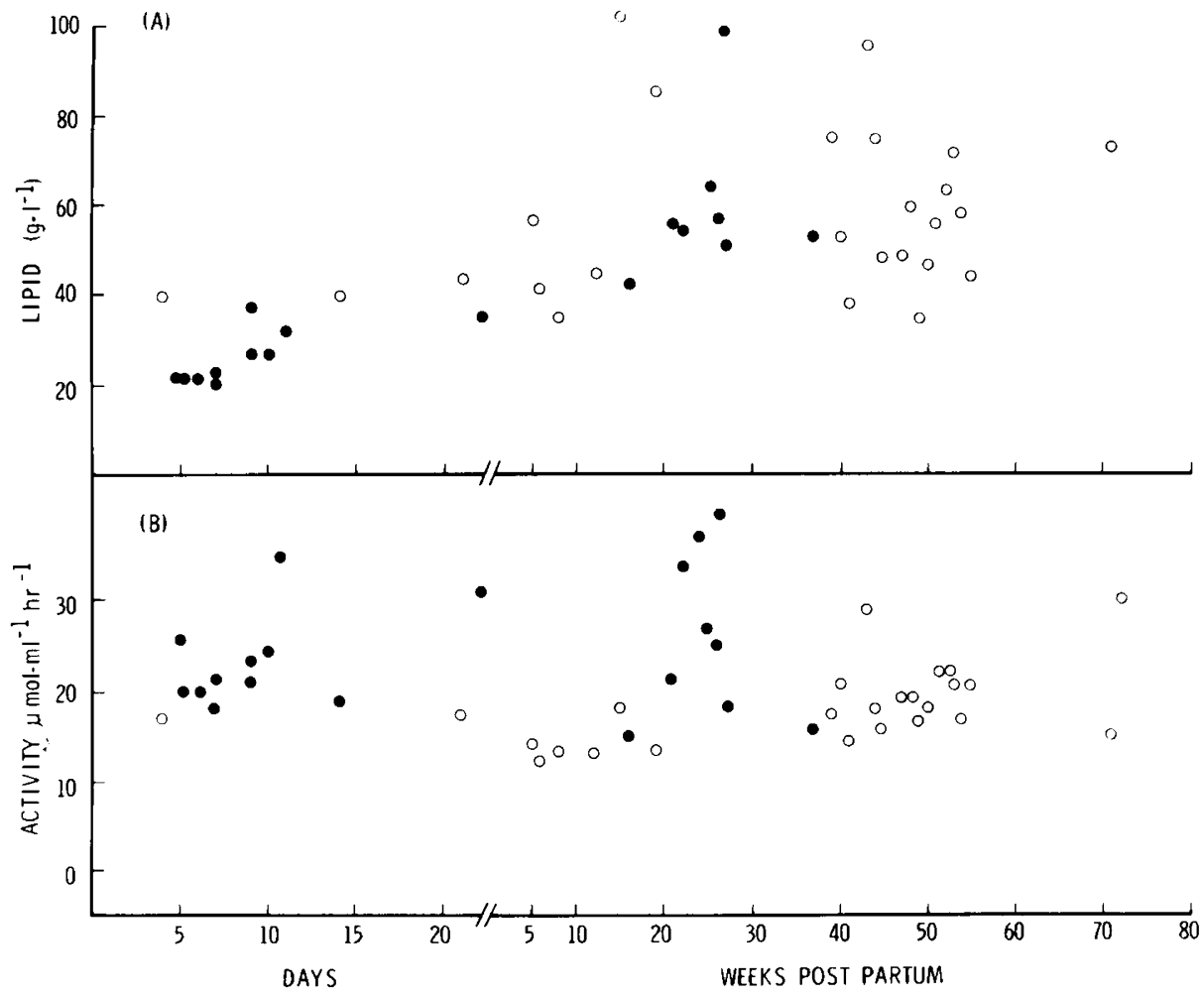

Fig. 4. The lipid concentration and lipolytic activity of milks collected at different stages of lactation. milks from a number of different women. milks from one woman.

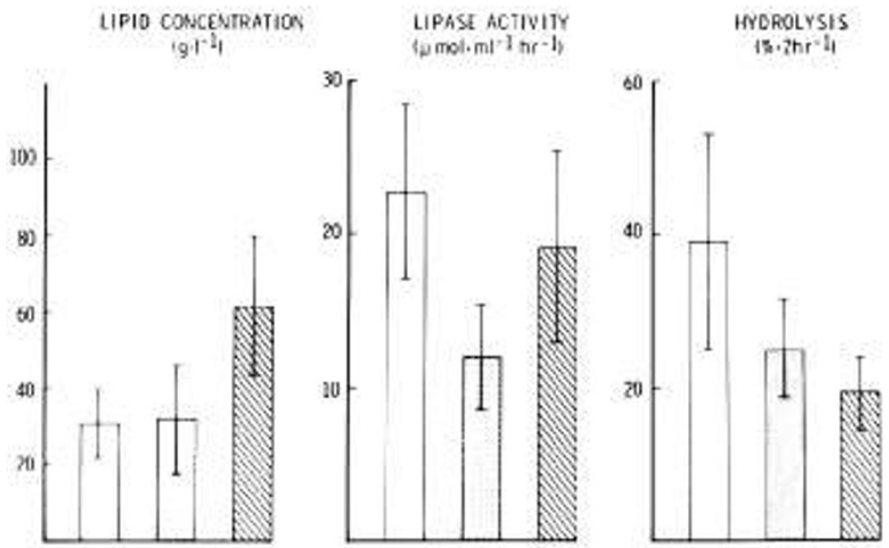

Fig. 5. The mean ( \pm 1 S.D.) lipid concentration, lipolytic activity and $\%$ hydrolysis of milk lipid in $2 \mathrm{~h}$ of three groups of milks. $\square$ immature milks after feed $(n=15)$. mature milks before feed $(n=5)$. (The same milks as in Fig. 3). 四 mature milks after feed $(n=28)$.

to follow lipase activities during a feed. Figure 3 shows the lipid concentration and lipase activity of 5 mature milk samples collected from three women from the same breast both before and after nursing. The lipid concentration increased significantly $(P$ $<0.01$ ) from $32.0 \pm 14.6$ to $75.0 \pm 20.7 \mathrm{~g} \cdot \operatorname{liter}^{-1}$ during the course of a feed as did the lipase activity $(11.93 \pm 3.28$ to $21.80 \pm 4.97$ $\mu$ mole $\cdot \mathrm{ml}^{-1}$ milk $\cdot \mathrm{h}^{-1} ; P<0.02$ ). The \% lipid hydrolysed (35) in $2 \mathrm{~h}$ was not significantly different before and after the feed (25.14 \pm 6.4 and $17.88 \pm 2.03$ respectively).

During different stages of lactation. The lipolytic activity and lipid content of 45 milks collected from 4 days to $72 \mathrm{wk}$ postpartum are shown in Figure 4. There were no differences in lipase activity during lactation but the lipid concentrations tended to be lower in the immature compared to the mature milks. When the milks collected within the first 15 days of lactation were compared to those obtained later (Fig. 5) the mean lipase activities were similar

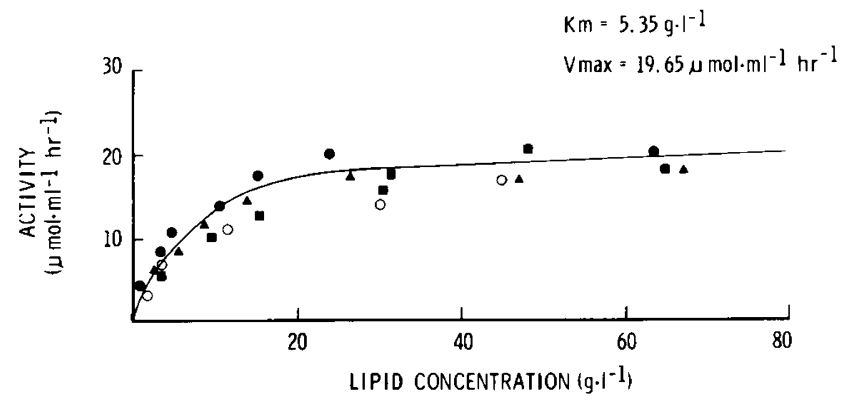

Fig. 6. Lipolytic activity as a function of substrate concentration using four different milks $(O, \boldsymbol{Q}, \Delta, \square)$. The lipid concentration was the concentration after reconstitution of the separated lipid and milk serum.

$\left(22.8 \pm 5.7\right.$ and $19.2 \pm 6.2 \mu$ mole $\cdot \mathrm{ml}^{-1} \cdot \mathrm{h}^{-1}$ respectively), whereas the lipid contents were significantly different $(31.0 \pm 8.8$ and 61.3 $\left.\pm 18.3 \mathrm{~g} \cdot \operatorname{liter}^{-1} ; P<0.001\right)$. As a result, the \% lipid hydrolysed in $2 \mathrm{~h}$ by the early milks was significantly greater $(P<0.001)$ than the later milks $38.9 \pm 14.0$ and $19.3 \pm 4.8 \%$ respectively).

\section{KINETICS OF LIPASE ACTIVITY}

The relationship of activity against increasing lipid concentration was determined on four separate occasions, using four different mature milks which had similar activities and which were collected at the end of a feed (Fig. 6). The apparent $K_{m}$ and $V_{\max }$ were found to be $5.35 \mathrm{~g} \cdot \mathrm{liter}^{-1}$ and $19.65 \mu \mathrm{mole} \cdot \mathrm{ml}^{-1} \cdot \mathrm{h}^{-1}$.

\section{PRODUCTS OF LIPOLYSIS}

The $\%$ of the total fatty acids in each lipid fraction before and after $4 \mathrm{~h}$ of in vitro lipolysis is shown in Table 1 . The \% fatty acid composition of these lipid fractions was also determined before and after lipolysis (Table 2). The composition of the triglyceride fraction remained essentially unchanged after lipolysis and was similar to that previously reported (13). The free fatty acid fraction 
prior to lipolysis contained the complete spectrum of fatty acids

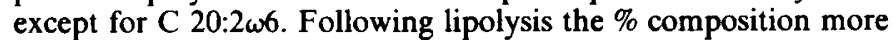
closely resembled that of the triglyceride fraction. The specificity of the bile salt stimulated lipase for particular fatty acids of triglyceride was examined by comparing the \% conversion of the fatty acids from the triglyceride to the free fatty acid fraction (last column of Table 2). Three fatty acids (C 20:1 $\omega 9,20: 2 \omega 6$ and 20: $5 \omega 3 / 22: 1 \omega 9)$ seemed relatively resistant to lipolysis $(0-16 \%)$ whereas the \% conversion of the other fatty acids were essentially similar (32.9-50\%). The fatty acid composition of the monoglyceride and diglyceride fractions before and after lipolysis differed markedly. In the mono- and diglyceride fractions of the fresh milk, there was no palmitic acid and, apart from some C 20:0 in the diglyceride fraction, no fatty acid chain longer or more unsaturated than oleic acid. Following lipolysis, the monoglyceride fraction contained the full spectrum of fatty acids except for C 12: $0,20: 2 \omega 6$ and $20: 5 \omega 3 / 22: 1 \omega 9$. The latter fatty acid was, however, found in the diglyceride fraction which did not contain C 12:0, oleic acid or any fatty acid longer or more unsaturated than 20 : $1 \omega 9$.

\section{DISCUSSION}

This study of the bile salt stimulated lipase activity in human milk differs from other similar studies in the choice of assay system. Fresh whole milk was used as the source of both enzyme and substrate as this more closely approximates the in vivo situation than the more conventional assays. Because of this different methodologic approach it was interesting to compare the results of the present study with the detailed investigations of others $(8$, $18,20)$.

We confirmed that bile salts were necessary for lipolytic activity

Table 1. Percentage of the total fatty acids in each lipid fraction before and after lipolysis (4 h)

\begin{tabular}{lcc}
\hline & Before & After \\
\hline Triglyceride & 95.82 & 55.38 \\
Diglyceride & 0.30 & 2.52 \\
Monoglyceride & 0.39 & 7.47 \\
Free fatty acid & 3.20 & 34.63 \\
Mono/Diglyceride ratio & 1.30 & 2.96 \\
\hline
\end{tabular}

and that they also protected the enzyme against tryptic inactivation (unpublished observations). However, in contrast to Hernell et al. (18), we found an apparent specificity of the enzyme for glycine conjugated bile salts. Thus sodium glycocholate, but not taurocholate, activated the enzyme with an optimum concentration of $2 \mathrm{mM}$ which is within the physiologic range found in the small intestinal contents of the suckling infant $(2,5)$. Naismith and Cashel (28) have recently reported that taurocholic acid is more effective than glycocholic acid in stimulating pancreatic lipase activity. If the apparent specificity of the two lipase activities for different bile salts is confirmed, it removes potential competition between the two enzymes for bile salts whose concentration is reduced in the newborn period. The fact that the addition of sodium taurocholate did not effect the stimulation of activity by glycocholate also supports this suggestion.

The lipolytic activities reported in this study are considerably lower (by a factor of approximately 70 ) than those reported by Hernell et al. (19). This is most likely explained by the very different assay procedures used. In the conventional methods, the in vitro assay conditions are optimised to give maximal activities. The physical state of the substrate is also different in the two systems, as the fat globules of breast milk are surrounded by a membrane which is likely to constitute a physical barrier between the enzyme and its substrate. The physical state of the enzyme could also be altered during separation from its natural environment which is necessary for the conventional assays. In one study using a single milk, Hernell et al. did compare the activity obtained using both a heat inactivated milk and an artificial emulsion of triolein as substrate (18). They found a greater activity (factor of 7) with the emulsion compared to the milk, which explains in part the reduced lipolytic activities found in this study. The observed activities do, however, agree with certain in vivo observations. Williamson et al. (32), for example, carried out balance studies on premature infants and found that pasteurisation of breast milk reduced fat absorption by approximately $30 \%$. This compares favourably with our finding of a mean hydrolysis of $38.9 \pm 14.0 \%$ of milk triglyceride in immature milk in $2 \mathrm{~h}$, the estimated transit time between the duodenum and ileum (17).

The changes in lipid content and lipase activities with time after parturition and during the course of a feed are interesting. The increase of lipid during lactation and a feed has been previously reported both by ourselves and by others $(13,23,25)$. The increase in lipase activity during a feed has not, as far as we are aware,

Table 2. Percentage fatty acid composition before and after in vitro lipolysis $(4 \mathrm{~h})$

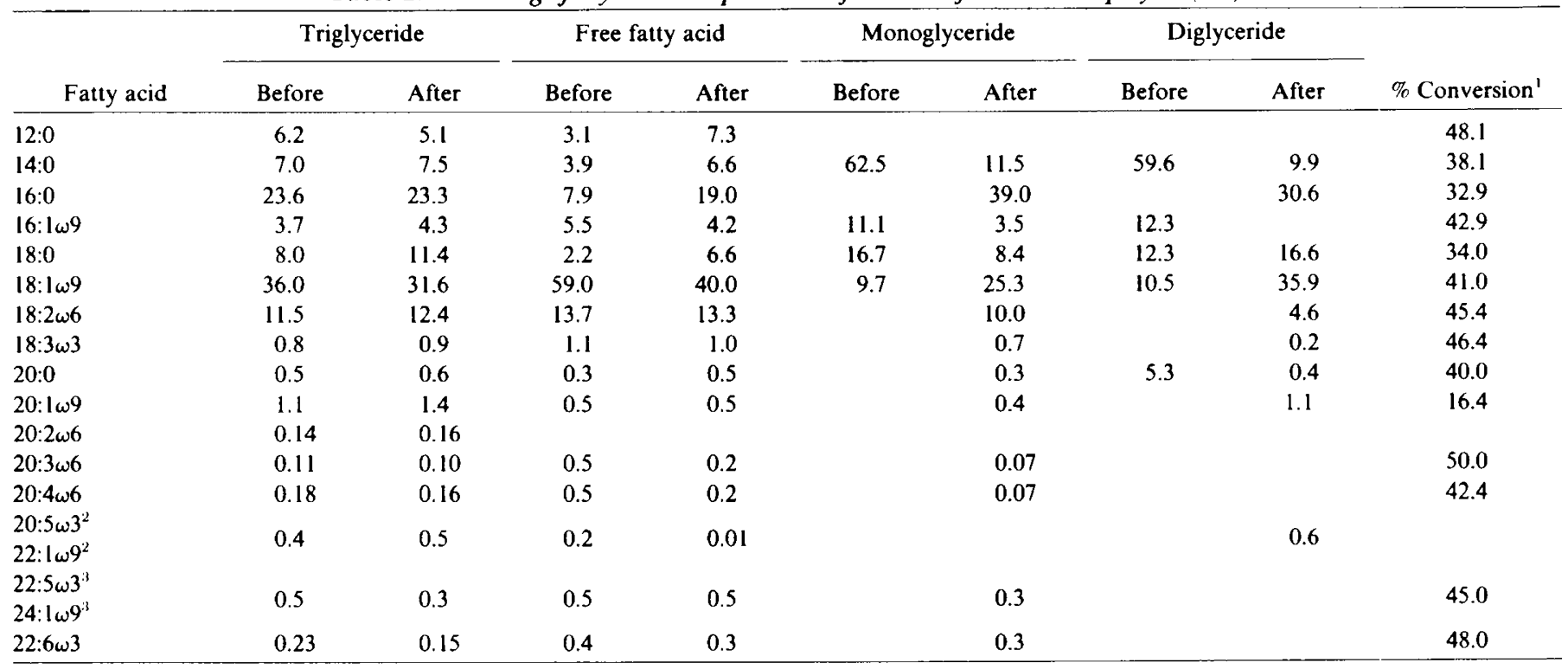

$1 \%$ conversion of fatty acids of triglyceride to free fatty acids.

2 These two fatty acids do not separate on $10 \%$ polyethylene glycol adipate.

${ }^{3}$ These two fatty acids do not separate on $10 \%$ polyethylene glycol adipate. 
been previously reported. The fact that it showed a similar (approximately 2 -fold) increase to the lipid concentration suggests that they may be secreted in parallel. The hind milk, therefore, contains an increased concentration of lipid and lipolytic activity at a time when pancreatic lipase activity is reduced compared with that of the adult. The observation that lipase activities did not change throughout lactation is in agreement with previous reports that colostrum has a normal lipase activity $(19,21)$. The fact that immature milks have a lower lipid concentration than mature milks suggests that lipid production and bile salt stimulated lipase secretion by the mammary gland develop at different rates. As the reduced lipid concentration of the immature milk is at least five times the apparent $\mathrm{Km}$ of the reaction, lipolysis will still proceed at maximum velocity. Thus the amount of lipolytic products available for absorption will be approximately the same from both immature and mature milks. The changes in lipid concentration following parturition could result from reported changes in lipoprotein lipase activity in both human milk and mammary gland tissue of animals. Very low levels of lipoprotein lipase activity have been found in colostrum (21). Lower activities have been reported in milk obtained 4-5 days after parturition than in later samples (19). This serum stimulated lipase activity in the mammary gland of the guinea pig $(27,29)$, rat (16) and cow (1) has been shown to increase during lactation.

The major product of lipolysis was found to be free fatty acids which agrees with the observations of Hernell et al. (20). Analysis of the fatty acid composition of the various lipid fractions showed that the enzyme had very little specificity for different fatty acids. The only exceptions were $C 20: 2 \omega 6$ and $C 20: 5 \omega 3 / 22: 1 \omega 9$, which were not hydrolysed, and $20: 1 \omega 9$ which seemed moderately resistant to hydrolysis. Thus, with these comparatively minor exceptions, all the fatty acids would be available for absorption as free fatty acids in proportions similar to that in the milk triglyceride.

In conclusion, the properties of the bile salt stimulated milk lipase are consistent with a role in the small intestine of the infant. Although the reported activities are reduced compared to those in the literature they can still account for approximately 40 and $20 \%$ of the fat absorbed by the breast fed baby during the first 15 days and thereafter respectively. Preliminary data also suggest that some of the characteristics of the milk lipase complement rather than duplicate those of pancreatic lipase, thus enriching the lipolytic system of the newborn.

\section{REFERENCES AND NOTES}

1. Askew, E. W.. Emery. R. S., and Thomas, J. W.: Lipoprotein lipase of the bovine mammary gland. J. Dairy Sci., 53: 1415 (1970).

2. Brueton. M. J., Berger, H. M., Brown. G. A.. Ablitt, L., Iyngkaran, N., and Wharton, B. A.: Duodenal bile acid conjugation patterns and dietary sulphur amino acids in the newborn. Gut, 19: 95 (1978).

3. Carta, S., and Tamburello, O.: L'attivita lipasica nel latte umano. Minerva Nipiol, 20: 81 (1970)

4. Documenta Geigy Scientific Tables Ed. K. Diem and C. Lentner, J. R. Geigy, Basle, Switzerland.

5. Encrantz. J. C.., and Sjovall, J.: On the bile acids in duodenal contents of infants and children. Clin. Chim. Acta, 4: 793 (1959).

6. Folch. J.. Lees, M., and Sloane. S. G. M.: A simple method for the isolation and purification of total lipids from animal tissues. J. Biol. Chem., 226: 497 (1957).

7. Fosbrooke, A. S., and Tamir, I. A.: A modified method for the preparation of methyl esters of a mixture of medium chain and long chain fatty acids. Clin. Chim. Acta, 20: 517 (1968).

8. Fredrikzon, B., Hernell, O., Blackberg, L., and Olivecrona, T.: Bile salt stimulated lipase in human milk, evidence of activity in vivo and of a role in the digestion of milk retinol esters. Pediatr. Res., 12: 1048 (1978).

9. Freudenberg, E.: Die Frauenmilch-Lipase. (Karger, Basel 1953).

10. Freudenberg, E.: A lipase in the milk of the gorilla. Experentia, 22: 317 (1966).

11. Galanos, D. S., and Kapoula, V. M.: Isolation of polar lipids from triglyceride mixtures. J. Lipid Res., 3: 134 (1962).

12. Hall, B.: Changing composition of human milk and early development of an appetite control. Lancet, I: 779 (1975).

13. Hall, B.: Uniformity of human milk. Am. J. Clin. Nutr., 32: 304 (1979).

14. Hall, B., Muller, D. P. R.., and Harries, J. T.: Studies of lipase activity in human milk. Proc. Nutr. Soc., 38: 114A (1979)

15. Hamosh, M. Fat digestion in the newborn: role of lingual lipase and preduodenal digestion. Pediatr. Res. 13:615 (1979).

16. Hamosh, M., Clary, T. R., Chernick, S. S., and Scow. R. O.: Lipoprotein lipase activity of adipose and mammary tissue and plasma triglyceride in pregnant and lactating rats. Biochim. Biophys. Acta, 210: 473 (1970).

17. Henderson, S. G.: The gastrointestinal tract in the healthy newborn infant. Am. J. Roentgenol., 48: 302 (1942)

18. Hernell, O.: Human milk lipase. III. Physiological implications of the bile salt stimulated lipase. Europ. J. Clin. Invest., 5: 267 (1975).

19. Hernell, O., Gebre-Medhin. M.. and Olivecrona. T.: Breast milk composition in Ethiopian and Swedish Mothers. IV. Milk lipases. Amer. J. Clin. Nutr.. 30: 508 (1977).

20. Hernell, O., and Olivecrona. T.: Human milk lipases II. Bile salt stimulated lipase. Biochim. Biophys. Acta. 369: 234 (1974).

21. Hernell. O., and Otivecrona. T.: Human milk lipases I. Serum stimulated lipase. J. Lipid Res., 15: 367 (1974).

22. Heyndrickx, G. V.: Investigations on the enzymes of human milk. Ann. Paediatr., 198: 356 (1962).

23. Hytten, F. E.: Clinical and chemical studies in human lactation. Brit. Med. J., I. 175 (1954).

24. Jubelin, J., and Boyer. J.: The lipolytic activity of human milk. Europ. J. Clin. Invest., 2: 417 (1972).

25. Macy, I. G.: Composition of human colostrum and milk. Am. J. Dis. Child., 78: 589 (1949).

26. Marfan, A. B.: Allaitement naturel et allaitement artificiel. Presse Med., 9: 13 (1901).

27. McBride, O. W.. and Korn, E. D.: The lipoprotein lipase of mammary gland and the correlation of its activity to lactation. J. Lipid Res., 4: 17 (1963).

28. Naismith, D. J., and Cashel, K. N.: Taurine in breast milk: a role in fat utilisation Proc. Nutr. Soc., 38: 105A (1979).

29. Robinson, D. S.: Changes in the lipolytic activity of the guinea pig mammary gland at parturition. J. Lipid Res., 4: 21 (1963).

30. Watkins, J. B.. Szczepanik. P., Ingall, D., Klein. P. D., and Lester, R.: Bile salt metabolism in the newborn infant: measurement of pool size and synthesis by stable isotopic technique. N. Engl. J. Med., 288: 43I (1973).

31. Widdowson. E. M.: Scientific Foundations of Paediatrics. Eds J. A. Davies and J. Dobbing, p. 49 (Heinemann, London 1974).

32. Williamson, S., Finucane, E., Ellis, H., and Gamsu, H. R.: Effect of heat treatment of human milk on absorption of nitrogen, fat, sodium, calcium and phosphorus by preterm infants. Arch. Dis. Child. 53: 555 (1978).

33. Zoppi, G., Andreotti, G., Pajno Ferrara, F., Njai, D. M., and Gaburro, D. Exocrine pancreas function in premature and full term neonates. Pediatr. Res., 6: 880 (1972).

34. Milks collected during the first 5 days postpartum are termed colostrum; those from 6-10 days are termed transitional and mature milk is that obtained after 15 days postpartum (4). In this report. we have termed all milks collected during the first 15 days postpartum as immature and those after 15 days as mature.

35. The percentage lipid hydrolyzed here and elsewhere is the concentration of the free fatty acid released expressed as a percentage of the total fatty acid present in the milk triglyceride.

36. The authors wish to thank Dr. D. Harvey (Queen Charlotte's Maternity Hospitai, London W.1.) for allowing us to study the milk from women under his care and the staff of Victoria-Ward for their help and cooperation. We would also like to thank Professor O. H. Wolff and Dr. J. T. Harries for their helpful advice during the course of the study. B. Hall is grateful to Farley Health Products Lid. for financial support.

37. Requests for reprints should be addressed to: Dr. D. P. R. Muller, Department of Child Health. Institute of Child Health, 30 Guilford St.. London WCIN IEH, England.

38. Received for publication March 24, 1981.

39. Accepted for publication July $9,1981$. 